\title{
VŠEOBECNÝ PŘEHLED A/NEBO TEMATICKÉ STUDIUM? PODNĚTY K ZAMÝŠLENÉ REVIZI RVP ${ }^{1}$
}

\author{
Eduard Hofmann, Michaela Spurná, Petr Knecht
}

\begin{abstract}
This paper aims to encourage reflections and debates on changing the concept of geographical education in the Czech curriculum. The basis for this reflection are conducted surveys in which we have identified, with the help of Catling's typology, a type of concept that prevail in the curriculum documents of the RVP and among the future geography teachers. The required idea of geographical thinking supported by the International Charter on Geographical Education and current foreign trends is not sufficiently reflected in the curriculum documents of the RVP as well as in the geographical thinking of future geography teachers. The survey has shown that the factual concept of teaching geography is so deeply embedded in RVP documents as well as in the minds of students of geography teaching that there is an apparent space for the development of geographical thinking.
\end{abstract}

Keywords: geographical education, geographical thinking, Catling's typology

\section{Úvod}

Geografie, a s ní související výuka zeměpisu, už dávno ztratila popisný charakter. Geografické myšlení je v anglo-americkém geografickém vzdělávání motorem pro aktivní poznávání dnešního světa. Geografie je chápána jako vysvětlující disciplína založená na tematickém studiu prostorových interakcí lidí a prostředí. Tematické studium překonává tradiční popisnou geografii př́edevším tím, že akcentuje hlubší uvažování nad geografickými fenomény zasazené do širšího kontextu dílčích geografických disciplín. Jinými slovy, jedná se o přesun cílů geografického vzdělávání od utváření deklarativních znalostí k utváření znalostí procedurálních (Leat, 1998; Kinninment, 2001).

Myšlenka tematického studia v geografii i v geografickém vzdělávání není nová (srov. např. Kühnlová, 1997; Karvánková, 2013). Tematické studium bylo ukotveno jako jeden z možných př́stupů již v prvním vydání Mezinárodní charty geografického vzdělávání (Haubrich, 1992). Od prvního vydání Charty počátkem 90. let minulého století se několikanásobně zrychlil a zkvalitnil př́stup k informacím a moderní informační technologie jsou neustále na vzestupu.

1 Článek je výstupem výzkumného projektu GA18-08315S Pojetí geografie a geografického vzdělávání: pohled učitelů podpořeného Grantovou agenturou České republiky (GAČR). 
$\mathrm{Z}$ tohoto důvodu se přsunujeme od studia faktografie $\mathrm{k}$ práci $\mathrm{s}$ informacemi a jejich využití v konkrétních př́ípadech.

Řada učitelů však stále jen těžce a pomalu opouští zažité výukové stereotypy, kdy jsou žáci postaveni do role pasivních konzumentů učebnicových a učitelem vybraných sdělení o světě, ve kterém žijeme. Tento fakt nezlepšilo ani zavedení dvoustupňového kurikula. Po více než deseti letech se začíná diskutovat o rozsáhlejší inovaci (revizi) rámcových vzdělávacích programů. Důvodem inovace závazných dokumentů není pouze jejich přirozené zastarávání, ale také skutečnost, že rozsáhlejší výzkumy i výzkumné sondy uskutečněné v rámci výuky jednotlivých vyučovacích předmětů ukázaly, že učitelé myšlenku dvoustupňového kurikula ve větší míře nepřijali (např. Straková, 2013).

\section{Jsou RVP dostatečně vstřícné k potřebám učitelů?}

Skutečnost, že RVP pro jednotlivé stupně vzdělávání jsou pojaté rámcově, nevede $\mathrm{k}$ tomu, aby se učitelé soustřed'ovali především na jejich hlavní úkol, kterým je vedení výuky podle vytvořeného inovativního kurikula, které se může přizpůsobit např. tematickému zpracování učiva. Učitelé si kurikulum musí nejprve dotvořit sami, jsou v roli spolutvůrců kurikula, na kterou nemají dostatek času. Pokud se k inovativní tvorbě kurikula dostanou, tak různé změny prosazují intuitivně, jelikož chybí dostatečný prostor pro ověření zavedení inovace. Učitelé tím nahrazují i práci (schéma 1 a 2), kterou by měl zastávat Národní ústav pro Vzdělávání (dř́ive VÚP). Tyto ústavy ve světě fungují a velkou část této práce $\mathrm{s}$ konkretizací, sledováním a zaváděním změn v kurikulu vykonávají. Jinými slovy, přesnější návod, co a jak má učit, $v$ rukou učitelů vytváří paradoxně daleko větší svobodu, protože učitel má mnohem víc času na přemýšlení, jak výuku obohatit či zpracovat (schéma 1). Současné RVP jsou vytvářené pro jednotlivé typy a stupně škol, ale nejsou mezi nimi vytvořené návaznosti. Když učitelé na jejich základě tvoří školní vzdělávací programy, nap̌r. pro II. stupeň základní školy, tak se od nich očekává, že vědí, k čemu žáci došli na I. stupni, jak a v čem navázat a k čemu dojít. Učitel si může jen zhruba domýšlet, případně vyvinout téměř detektivní práci, aby z RVP pro jednotlivé stupně škol nějak informace vyhledal a upravil, jelikož tvůrci jednotlivých RVP tuto situaci neřeší. Jenže to z hlediska času není $\mathrm{v}$ jejich silách, a tak dochází $\mathrm{k}$ rychlému intuitivnímu jednání. Často někteří postupují podle zavedených kolejí a hlavně podle učebnic, které zmíněný problém taktéž neřeší. Otázkou je, nakolik je současná inovativní revize kurikula dobře plánována a promýšlena, aby moderní geografické vzdělávání mohli učitelé všech stupňu škol uchopit a rozpracovat. 
Schéma 1: Běžný postup tvorby kurikula

Scheme 1: A common curriculum development process

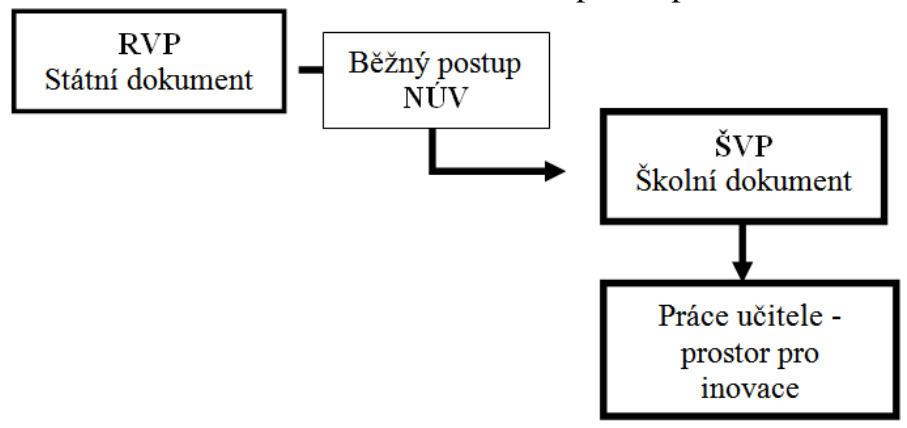

Schéma 2: Specifický postup tvorby kurikula v Česku,

Scheme 2: Specific course of curriculum creation in the Czech Republic

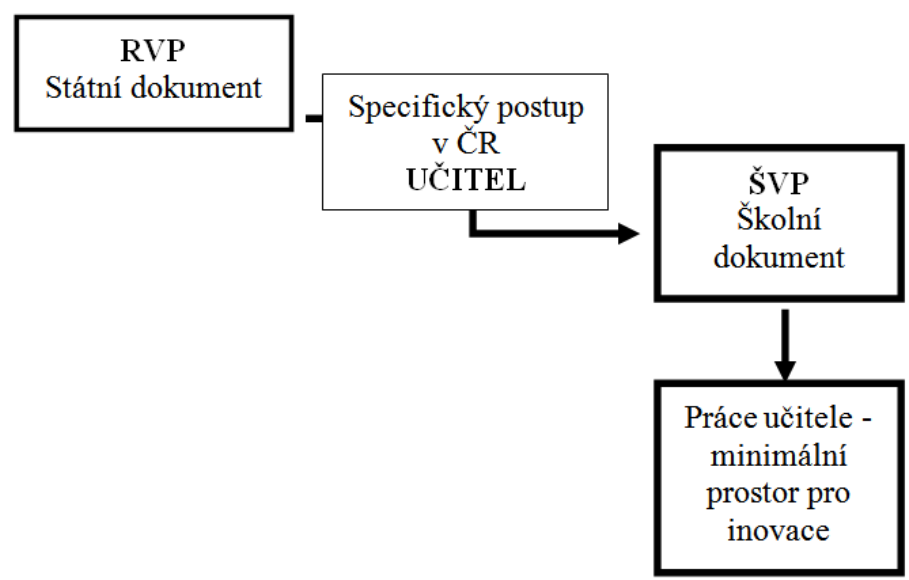

Domníváme se, že nyní je vhodná doba pro otevření debaty nad tím, do jaké míry současná podoba geografického vzdělávání reflektuje aktuální stav poznání v didaktice geografie, ale také potřeby žáků i společenská očekávání (souhrnně viz Edelson et al., 2013). Rádi bychom do debaty o budoucnosti geografického vzdělávání v Česku přispěli dílčí podkladovou analýzou, jejímž cílem bylo zjistit, jaká pojetí geografie jsou akcentována ve stávající verzi rámcových vzdělávacích programů a jakým pojetím geografie disponují studenti učitelství zeměpisu/geografie. Výzkumné šetření, které zahrnovalo české studenty učitelství zeměpisu, jsme doplnili o podrobnější analýzu odpovědí vybrané skupiny studentů učitelství zeměpisu z PdF MU. 


\section{Metodika šetření}

Základní inspirací pro výzkumné šetření se stala Catlingova typologie (Catling, 2004), která pracuje s devíti různými typy pojetí geografie a geografického vzdělávání. Jednotlivé typy pojetí geografie jsme arbitrárně rozdělili do dvou základních skupin, které sémanticky odráží dvě současná převládající pojetí geografie u studentů učitelství i u učitelů zeměpisu. První skupina se zaměřuje na všeobecný přehled ${ }^{2}$ (jehož součásti jsou terminologie, znalost a popis pravidel a složek), který sebou nese základní otázky kdo, co, kde a kdy a nevyžaduje znalost souvislostí mezi geografickými jevy (skupina „faktografư“ alias obecných geografü). Druhá skupina typů jde dál za tento všeobecný přehled tak, že s jeho užitím se učitelé podrobněji zabývají souvislostmi a vztahy mezi geografickými jevy. Jedná se o přemostění požadovaných znalostí do tvorby otázek (proč, jak a jaké) vyžadující vyšší úroveň kognitivních procesů u žáků. Tato druhá skupina agreguje 8 dalších typů pojetí (skupina „,earthistů“, „,interakcionistů“, ,placeistů“, „environmentalistů“, „facilitátorư“ a „syntetizátorü“ apod.), které lze vystihnout pojmy, jako jsou (kritické) myšlení a rozvoj myšlení.

S pomocí takto adaptované Catlingovy typologie pojetí geografie jsme dále provedli tematickou obsahovou analýzu oblastí a oborů zaměřených na geografii v RVP, která odkryla zaměření sledovaných pasáží v RVP - charakteristiky vzdělávací oblasti a očekávaných výstupů. Typologii pojetí geografie jsme následně použili také pro kategorizaci výpovědí studentů učitelství zeměpisu/geografie, které byly sbírány dotazníky se dvěma otevřenými otázkami zaměřenými na význam a účel geografie a geografického vzdělávání.

Obsahová analýza částí (oddílů) RVP (ZŠ a gymnázia) ukázala jasné disproporce mezí tím, co je požadováno oborem (charakteristika oboru) a tím, co je očekáváno od žáků (očekávané výstupy). Od oboru se vyžaduje především přemýšlení nad základními geografickými jevy v souvislostech a interakcích. Po žácích se však vočekávaných výstupech vyžaduje dosáhnout všeobecného přehledu (v podobě aktivních sloves ,vyjmenuj, ukaž či popiš“).

Shluková analýza výpovědí studentů učitelství geografie (např́ic Českem) odhalila, jak smýšlí studenti o geografii a geografickém vzdělávání. Jejich volné výpovědi tvořily shluky pojetí, které se zaměřovaly bud' právě na všeobecný přehled a nic jiného (jen „,faktografický“ typ pojetí) nebo na kritické - geografické - myšlení, ve kterém se ukázaly úzké vztahy mezi zbylými typy pojetí. Touto shlukovou analýzou se potvrdilo jednak naše prvotní arbitrární rozdělení typů pojetí do dvou skupin, ale také se ukázala jasná charakteristika budoucích učitelů. U studentů učitelství geografie převažoval typ pojetí „faktografa“, jinými slovy,

${ }^{2}$ Liesmann (2008) charakterizuje všeobecný přehled jako encyklopedismus a faktografii bez chápání souvislostí mezi fakty. 
geografické vzdělávání bylo dle jejich slov především o tvorbě všeobecného přehledu u žákủ. ${ }^{3}$

\section{Pět kroků k přeměně myšlení studentů}

V návaznosti na uvedené výsledky byl u 26 studentů PdF MU rámci výuky didaktiky geografie podrobněji zjišt'ován stav jejich chápání dosavadní výuky zeměpisu. Očekávali jsme, zda se opravdu potvrdí skutečnost, že „správnou cestou“, která vede ke kvalitnímu zeměpisnému vzdělávání je všeobecný přehled, který je reprezentován především zásobou faktografie ze studovaného oboru. Tento faktografický základ studenti považují jako nezbytný k tomu, aby jedinci postupně dospěli až do stadia, kdy základ užijí, aplikují a s jeho pomoci vyřeší situace $\mathrm{v}$ běžném životě. $\mathrm{K}$ potvrzení či vyvrácení tohoto zaužívaného př́stupu mělo pomoci následujících pět kroků, které jsme studentům učitelství geografie předložili.

1. krok: studenti obdrželi jednoduché zadání, kde měli napsat vše, co vědí o stanoveném regionu: o Kazachstánu.

2. krok: stejné zadání a stejný region, ale byl povolený atlas a upozornění, že mohou odpovídat $\mathrm{v}$ souvislostech.

3. krok: zadání bylo rozšířené o novinový článek - rozbor, kladení zeměpisných otázek, hledání odpovědí.

4. krok: vyžadován popis destinace s důrazem na vztahy mezi jednotlivými fakty, generalizace - souhrnný text.

5. krok: vyžadováno nalezení obecného tvrzení - konceptu, který lze na př́íkladu všeho předchozího zformulovat.

Obr. 1: Výstupy z prvního a druhého kroku (bez mapy, s mapou)

Figure 1: First and second step outputs (no map, map)

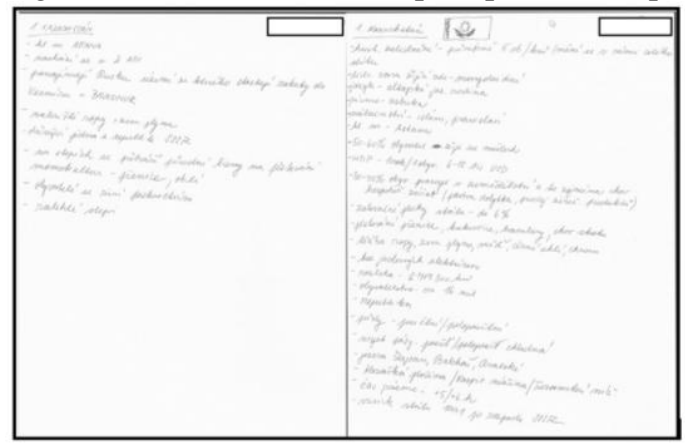

3 Podrobnějš̌i a detailnější výsledky z výzkumu budou publikovány v podobě úzce zaměřených časopiseckých studií. 
Doslovný přepis první stránky:

Kazachstán, hl. město Astana; nachází se v Z Asii; pronajímají Rusku území ze kterého startují rakety do Vesmíru - BAJKONUR; naleziště ropy + zemního plynu; dřívější jedna z republik SSSR;

na stepích se přetvárí původní biomy na pěstování monokultur, pšenice, obilí; obyvatelé se živí pastevectvím; rozlehlé stepi

Doslovný přepis části druhé stránky:

Kazachstán, hustota zalidnění-průměrně 5 obyv. na $\mathrm{km}^{2}$ (mění se v rámci celého státu); lids., rasa zde žijící - mongoloidní; jazyk - altajská jazyková rodina; písmo - azbuka; náboženství - islám, pravoslavné; hl.m. Astana; $50-60 \%$ obyv. žije ve městech; HDP -1 rok/1 obyv. $6-12$ tis USD; $30-50 \%$ obyv. pracuje v zemědělství a to zejména chov hospodářských zviŕat; zalesněná plocha státu $6 \% ; \ldots$

Podobně, jak lze vidět $\mathrm{z}$ přepisu textu $\mathrm{z}$ obr. 1 , odpovídalo i dalších 25 studentů. Je však třeba poznamenat, že to je výsledek absolventů, kteří prošli výukou zeměpisu na ZŠ, SŠ a Bc. studiem zeměpisu na vysoké škole, u kterých je již očekáván širší rozsah všeobecného přehledu. Tyto materiály, které si studenti vloží do svého portfolia, dokládají:

1. Přesvědčení, že encyklopedické pojetí regionální geografie ve studentech zanechalo jen velmi málo informací o rozmístění geografických jevů na Zemi, nehledě na souvislosti.

2. Utvrzení, že je mnohem důležitější naučit se pracovat s mapou a atlasem, se kterými jsou studenti schopni z této učební pomůcky vyčíst mnohem více informací.

Z výčtu informací podložených také mapou je zřejmé, že se studenti nedostali v kartografických dovednostech dál, než ke čtení mapy (srov. Hanus, Marada, 2014). Třetí krok měl pomoci studentům pracovat s informacemi. Geografické zdroje informací, kartografie a topografie je tematický celek, který považujeme za základ geografického vzdělávání. Ve vybraných článcích, které pojednávají o současném dění v různých částech světa, se skrývá řada užitečných geografických informací, které jsou jako stvořené pro kladení geografických otázek a hledání odpovědí, které by měly doložit, proč v určitém území fungují věci tak, jak fungují. Neméně důležité bylo i zjišt'ování, kterými nástroji vládne geografie, aby došlo k jejich porozumění. Studenti měli za úkol přečíst článek, podtrhnout si pojmy a věty, které souvisejí s geografickými informacemi, poté vytvořit na ně otázky a začít hledat odpovědi v různých zdrojích informací.

Ukázka článku (jedená se o rozhovor s fotbalistou Jeslínkem, který v té době hrál nejvyšší fotbalovou ligu v Kazachstánu). Stínování je použité pro slova či věty, na které následně studenti tvoří geografické otázky: 


\section{“Co přesně máte na mysli?}

Kazachstán je obrovská země. Na zápasy létáme standardně čtyři, pět hodin. Někdy i více. Letadla jsou starší. My máme čtyřicet let staré. $V$ zimě jsou kruté mrazy, čtyřicet pod nulou není výjimka. $V$ březnu a $\mathrm{v}$ dubnu se hraje jen na umělé trávě, při utkání je minus patnáct stupňủ, strašidelný vítr. Není to pak žádný hezký fotbal. Začínali jsme v polovině března, ale na př́rodní trávu se dostali druhý týden v květnu. A když říkám tráva, tak hodně přeháním. Je to udusaná hlína s trsy trávy. U nás ve třetí trrídě je lepši povrch. Zde pořád mrzne, hřiště nejsou vyhřívaná, tudíž terény jsou strašidelné. I proto mnohé týmy přešly na umělku."

Radek Malina (Astana), Sport.cz, Právo

Z ukázky je patrné, že prostřednictvím tohoto rozhovoru se dozvídáme o Kazachstánu mnoho geografických skutečností, které stojí za to si analyzovat a udělat si tak obrázek, jak vypadá současný život lidí v příslušném regionu. Vyznačování geografických skutečností proběhlo dobře, ale problematická byla formulace otázek, přičemž větší potíže studentů byly spojeny ve většině případů také s odpověd'mi na tyto otázky. Odpovědi byly stručné a neobsahovaly širší souvislosti. Nejhůře dopadl výsledek tvorby souvislého textu.

Ideální splnění všech kroků by vedlo $\mathrm{k}$ uvědomění si místa faktografie ve výuce, zejména tehdy, když by byla zeměpisu hypoteticky odebrána druhá vyučovací hodina týdně.

\section{Závěr}

Mezinárodní charta geografického vzdělávání vyšla v roce 1992. V Česku není jediné pracoviště vzdělávající učitele zeměpisu, které by na ni nepoukazovalo a studenty nevedlo ke geografickému myšlení. Geografické myšlení je z velké části založeno na kladení geografických otázek (Bednarz, 2003). Přesto se tato skutečnost po více než 26 let neprojevuje ve výsledcích. Kvalitní učební úlohy nejsou dobře zpracovány ani v učebnicích zeměpisu (Knecht, Lokajíčková, 2013). Učební úlohy jsou základem správně pojatého vzdělávání, protože jejich prostřednictvím se vytvářejí př́ležitosti $\mathrm{k}$ učení, $\mathrm{tj}$. neměly by být jen prostředkem ke zjišstování vědomostí. S přihlédnutím k pojetí, které vykazují současní studenti a budoucí učitelé geografie, jsou očekávané výsledky v nedohlednu. K jejich správnému směřování by mohlo napomoci tematické uchopení cílů geografického vzdělávání v RVP, které by eliminovalo současný stav charakterizovaný faktograficky orientovanou výukou na všech stupních a typech škol.

Aktuálním slibným počinem kolektivu autorů z PřF UK a PdF MU je certifikovaná metodika „Koncepce geografického vzdělávání” (www.eGeografie.cz). Jejím záměrem je předložit propracovanou národní koncepci geografického všeobecného vzdělávání, která má umožnit překlenout mezeru mezi 
státem stanoveným RVP a školní úrovní kurikula (Marada et al., 2017). V tomto veřejně př́stupném materiálu se uvádí, že primárním cílem geografického vzdělávání by mělo být vzdělávat a vychovat občana zodpovědně jednajícího v prostoru (Doubrava, 2018). Prvním krokem k jeho výchově je rozvinutí geografického myšlení, čemuž by měly předcházet aktivity spojené $\mathrm{s}$ odbouráváním již zakořeněného myšlení.

\section{Literatura}

DOUBRAVA, L. 2018. Zeměpis žáky nebaví. In Učitelské noviny. č. 10/2018, s. 47.

BEDNARZ, S. W. 2003. Nine years on: Examining implementation of the National geography standards. In Journal of Geography. vol. 102, no. 3, pp. 99109.

CATLING, S. 2004. An understanding of geography: The perspectives of English primary trainee teachers. In GeoJournal. vol. 60, no. 2, pp. 149-158.

EDELSON, D. C. - SHAVELSON, R. J. - WERTHEIM, J. A. - BEDNARZ, S. W. - HEFFRON, S. - HUYNH, N. T. 2013. A Road Map for 21st Century Geography Education. Washington: National Geographic Society.

HANUS, M. - MARADA, M. 2014. Mapové dovednosti: vymezení a výzkum. In Geografie. roč. 119, č. 4, s. 406-422.

HAUBRICH, H. 1992. International Charter on Geographical Education. Freiburg: International Geographical Union.

KARVÁNKOVÁ, P. 2013. Vývoj didaktiky geografie a nové trendy výuky zeměpisu v Česku. In Annales Universitatis Paedagogicae Cracoviensis Studia Geographica. roč. 4, s. 101-109.

KINNINMENT, D. (ed.). 2001. More thinking through geography. Cambridge: Chris Kington.

KNECHT, P. - LOKAJÍČKOVÁ, V. 2013. Učební úlohy jako př́ležitosti $\mathrm{k}$ rozvíjení a dosahování očekávaných výstupů: analýza koherence učebnic a RVP ZV. In Pedagogika. roč. 63, č. 2, s. 169-183.

KÜHNLOVÁ, H. 1997. Reflexe světových trendů v pojetí a obsahu perspektivního geografického vzdělávání v České republice. In Geografie-Sborník ČGS. roč. 102, č. 3, s. 161-174.

LEAT, D. 1998. Thinking Through Geography. Cambridge: Chris Kington.

LIESSMANN, K. P. 2008. Teorie nevzdélanosti. Praha: Academia.

MARADA, M. - ̌̌EZNÍČKOVÁ, D. - HANUS, M. - MATĚJČEK, T. HOFMANN, E. - SVATOŇOVÁ, H. - KNECHT, P. 2017. Koncepce geografického vzdělávání $v$ Česku. Certifikovaná metodika. www.egeografie.cz. Praha: Př́rodovědecká fakulta UK.

STRAKOVÁ, J. 2013. Jak dál s kurikulární reformou. In Pedagogická orientace. roč. 23 , č. 5, s. 734-743. 


\section{GENERAL OVERVIEW OR THEMATIC STUDY? SUGGESTIONS FOR THE INTENTIONAL RVP REVISION}

\section{Summary}

The paper describes conceptions of geography education that are embedded in Czech geography pre-service teachers and Czech state-level primary and secondary geography curriculum. We identified the predominant types of conceptions based on Castling's typology. We found that the required idea of geographic thinking supported by the International Charter of Geographical Education and current foreign trends is not sufficiently reflected in the curriculum documents and in the statements of pre-service teachers. The "globalist" type of encyclopedic (information-oriented) conception is prevailing. Thus, the space for the development of geographic thinking is considerably limited. The thematic oriented aims of geographic education in the curriculum documents could help to initiate the required geographic thinking in education.

doc. PaedDr. Eduard Hofmann, CSc.

Mgr. et Mgr. Michaela Spurná

doc. Mgr. Petr Knecht, Ph.D.

Katedra geografie PdF MU

Poříčí 7, 60300 Brno

Česká republika

E-mail: hofmann@ped.muni.cz, spurna@ped.muni.cz, knecht@ped.muni.cz 